\title{
Prostate Acinar Adenocarcinoma, Pleomorphic Giant Cell Variant
}

National Cancer Institute

\section{Source}

National Cancer Institute. Prostate Acinar Adenocarcinoma, Pleomorphic Giant Cell

Variant. NCI Thesaurus. Code C160818.

An extremely rare variant of acinar prostate adenocarcinoma characterized by the presence of giant, bizarre anaplastic cells with pleomorphic nuclei and lack of a spindle cell component. 